\title{
STUDENTS' MUSIC ASSOCIATION PROGRAMS IN CHINA:AN EMPIRICAL STUDY OF SELECTED SCHOOLS IN YAODU DISTRICT, SHANXI, CHINA
}

\author{
Li Jia \\ College of Music, \\ Shanxi Normal University, Linfen, Shanxi041099 \\ Ma Chunjie \\ Shanxi Xiaoyi Middle School, Lv \\ Liang, Shanxi, China
}

\begin{abstract}
The development of music associations has always been a research hotspot in the field of music education. In the process of music education, it is often the mutual penetration and promotion of music teaching and extracurricular music activities. With the deepening of the curriculum reform in China, students' associations are developing vigorously, and the activities of students' associations in music education tend to be diversified. This paper focus on the students' music associations of three selected schools at primary, secondary and tertiary levels in Yaodu District, Linfeng Shanxi Province, China. the research on the education and teaching of students' associations in music education in Yaodu District School, while achieving certain teaching results, still has some room to further develop. Towards the end, the study puts forward suggestions to promote the continued development of school music associations.
\end{abstract}

Key Words - Music Education, School Music Association

\section{INTRODUCTION}

The development of music associations has always been a research hotspot in the field of music education. In the process of music education, classroom music teaching and extracurricular music activities often penetrate and promote each other. Generally speaking, the domestic research on the development of music associations has been carried out from different dimensions: different types of schools, the construction of campus culture, the thinking of the development of music associations, the impact on quality education and so on. With the deepening of the domestic curriculum reform, student associations are booming, and the activities of student associations in music education tend to be diversified. The research of students' associations in music education in schools is of great importance to grasp the dynamic direction of students' thinking and innovate the research methods .

As an educational activity to improve students' aesthetic psychology and cultivate their social sentiments, music education is an important learning content that students can not lack in the process of learning. On the one hand, the research on student associations in school music education is in line with the dominant idea of "education oriented and moral education first" in China, and plays a positive role in cultivating all-round students in schools; on the other hand, it can also promote the practice of the basic task of aesthetic education in schools.

\section{LITERATURE REVIEW}

Music education is an important part of quality education in primary schools, which plays an important role in improving primary school students' music quality, aesthetic taste and stimulating positive energy. In recent years, China's primary school music associations have developed vigorously, and together with music classroom teaching, they constitute two important aspects of China's primary school music education (Li Wenyao, 2015).Under the promotion of the education department, music education in primary and secondary schools in China has made great achievements, and has increasingly become a powerful platform for the in-depth implementation of quality education, especially in promoting the physical and mental development of students. However, in the process of development, there are also many problems affecting its in-depth development ( $\mathrm{Fu} \mathrm{Li}, 2014)$. In recent years, with the emphasis on aesthetic education, primary school music education is getting better and better. In order to cultivate students' music practice ability and aesthetic ability, the secondary music classroom in primary schools is also booming 


\section{International Journal of Engineering Applied Sciences and Technology, 2021 \\ Vol. 6, Issue 1, ISSN No. 2455-2143, Pages 29-42 \\ Published Online May 2021 in IJEAST (http://www.ijeast.com)}

(Shen Hang, 2019). In addition, the status and role of aesthetic education in middle school education should be clarified, the relationship between aesthetic education and other education should be straightened out, and the ways and methods of aesthetic education should be explored. These are the problems that middle school educators need to study seriously (Jin Yuxiang, 1991)

\section{RESEARCH LOCATION}

This paper selects three schools in Linfen City. In order to fully reflect the current situation of music education and teaching of student associations in Yaodu District, this survey selects one local provincial Normal University (hereinafter referred to as School C), one provincial middle school (hereinafter referred to as School B) and one municipal primary school (hereinafter referred to as School A) as samples respectively. The research objective is to promote the healthy and orderly development of school music community and put forward reasonable suggestions accordingly.

\section{RESEARCH TOOLS}

There are three questionnaires designed in this survey, which are "questionnaire on music education of music associations in School C", "questionnaire on music education of music associations in School B" and "questionnaire on music education of music associations in School A". Each questionnaire consists of two parts: students' basic information and $t$ school music association survey.

The part of students' basic information includes students' gender and their love for music; The part of music education in School Association includes the reasons why students choose music association, the motivation to participate in music association, the degree of mastering the most basic music theory knowledge, the degree of mastering some music skills, whether they can participate in music association activities on time, the degree of support from parents, and the influence between culture class, etc.

\section{SAMPLING AND DISTRIBUTION QUESTIONNAIRES}

The selected respondents are members of music associations in three schools, including nine music associations in School C, four music associations in School B and twelve music associations in School A. In the process of the survey, with the support and cooperation of the student associations and instructors, the questionnaire was sent to the members of the music associations. 300 questionnaires (School C), 100 questionnaires (School B) and 100 questionnaires (School A) were sent to the members of the music associations of the three schools respectively. A total of 500 questionnaires were collected and 487 were retrieved, with an effective rate of $97.4 \%$.

\section{DATA ANALYSIS}

Investigation of music associations in School C

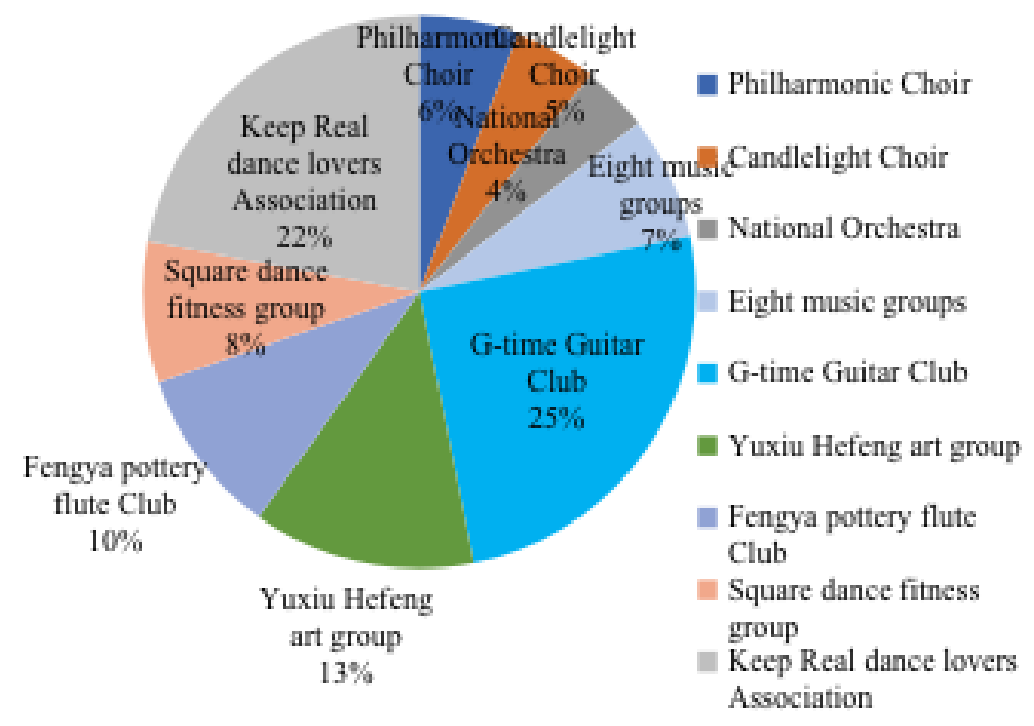

Figure1. Proportion of Participation in Music Associations of School C 
There are 47 student associations in School C, including 9 music associations: candlelight choir, Philharmonic Choir, National Orchestra, eight music group, g-time guitar association, Yuxiu and wind art group, elegant pottery flute association, square dance fitness group and keep real dance lovers Association. It accounts for $19.1 \%$ of the total number of the whole society, including vocal music, instrumental music, dance and other types, and various activities. The research found that the frequency of music activities of music associations is about 1-2 times a week.

Through investigation, the three groups with a large proportion of members are g-time guitar association, keep real dance lovers Association, Yuxiu and wind art group, which accounts for $60 \%$ of the total. It can be seen that college students prefer guitar, rock and modern dance with youthful vigor and trend than classical folk music groups. But the square dance fitness group, which is also a dance, is not as popular as the keep real dance lovers Association, but it also accounts for $8 \%$ of the total. It can be seen that with the popularity of the popular music entertainment forms of square dance in recent years, some college students are affected and interested in the popular music and entertainment forms of such relatives.

\subsection{Investigation of Music Associations in School B}

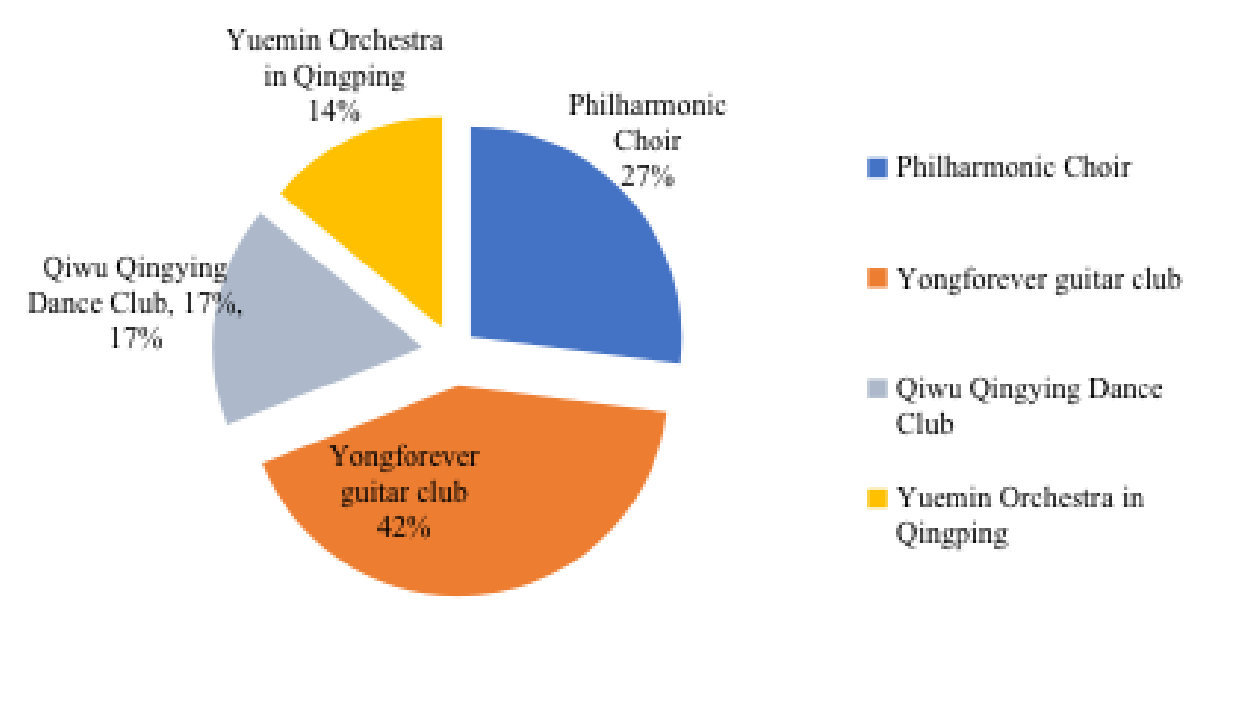

Figure2. Participation in Music Associations in School B

There are 33 student associations in School B, including 4 Music associations: Philharmonic Choir, Yongforever guitar association, Qiwu Qingying dance association and Qingping folk music orchestra, which account for $12 \%$ of the total association members of this school. It includes chorus, instrumental music and dance. The frequency of activities of three associations, including Philharmonic Choir, Qiwu Qingying dance association and Qingping Yuemin Orchestra, is once a month. Yongforever guitar association stands out among the four music associations, and its activities are more frequent than other associations, with 20 guitar teaching sessions per month. It can be seen that popular and rock music is more popular among middle school students, since they are most covered by the teaching of this association. Its members are more than the other three music associations, accounting for $42 \%$ of the total number of members participating in music associations. It can be seen that pop music still occupies the mainstream position in the current middle school students. Folk guitar music, electric guitar music and other pop music, such as rock music, blues, heavy metal music, are more likely to be favored by middle school students. Secondly, members of the Philharmonic Choir account for $28 \%$ of the total number of members of music associations. It can be seen that chorus art is still 


\section{International Journal of Engineering Applied Sciences and Technology, 2021 \\ Vol. 6, Issue 1, ISSN No. 2455-2143, Pages 29-42 \\ Published Online May 2021 in IJEAST (http://www.ijeast.com)}

popular among middle school students. Moreover, the instructor of the Philharmonic Chorus has a master's degree, and the guidance of chorus art is more professional comparing to other associations. The proportion of Qingping music folk orchestra and Qiwu Qingying dance association is close to each other, but Qiwu Qingying dance association is more likely to be favored by middle school students with a weak advantage of $2 \%$. Compared with the guitar association and Qingping folk music orchestra, this music association, which carries forward China's long history of Chinese folk music, appears to be smaller among middle school students with only 25 participants. This phenomenon reflects the current dilemma of the development and education of national music in middle school students.

\section{Survey of Music Associations in School A}

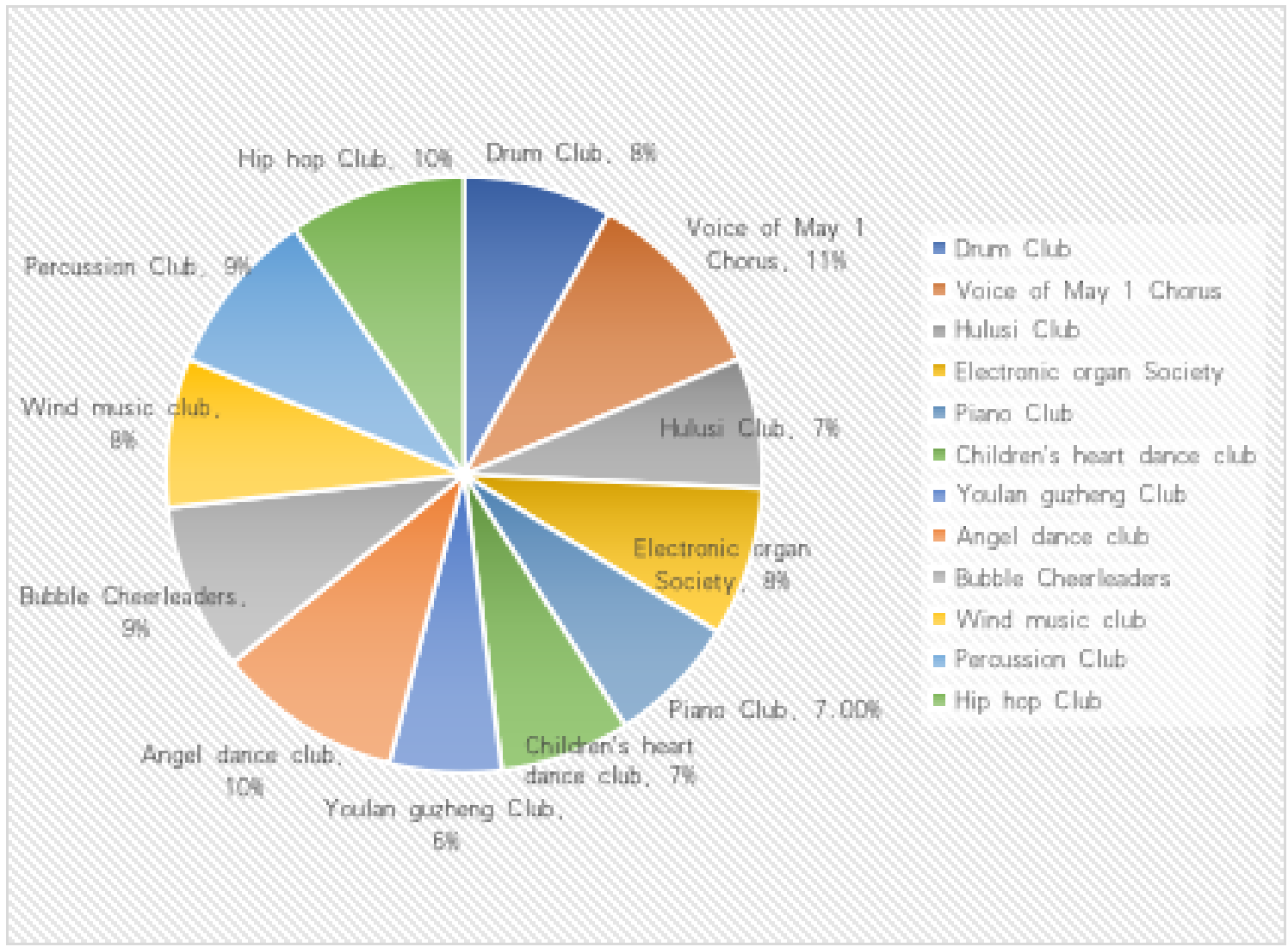

Figure3. Proportion of Students Participating in Music Associations of School A
There are 47 student associations in School A, including 12 music associations: Drum Music Association, Voice of May 1 chorus, Hulusi Association, Electronic Organ Association, Piano Association, childlike heart flying dance association, Youlan guzheng Association, Angel Dance Association, Bubble Cheerleading, Wind Music Association, Percussion Music Association and Hip-hop Dance Association, which accounts for about $25 \%$ of the total number of school associations. There are many kinds of music, including chorus, dance, wind music, folk music and so on. And every community has been highly valued by the school, and equipped with an coach with a bachelor's degree or above for the guidance of music activities. At the same time, each music association in School A has a regular activity frequency, which indicates that the school has allocated enough time for the music education of students' music associations. And the proportion of school students participating in various associations is relatively balanced, which shows that the school has carried out duly arrangement for students to participate in music associations, which reflects the school's attention to promote extra-curriculum activities.

Comparative Study of the Three Schools' Music Association Activity

\section{Analysis of Participants' Profile}


International Journal of Engineering Applied Sciences and Technology, 2021

Vol. 6, Issue 1, ISSN No. 2455-2143, Pages 29-42

Published Online May 2021 in IJEAST (http://www.ijeast.com)

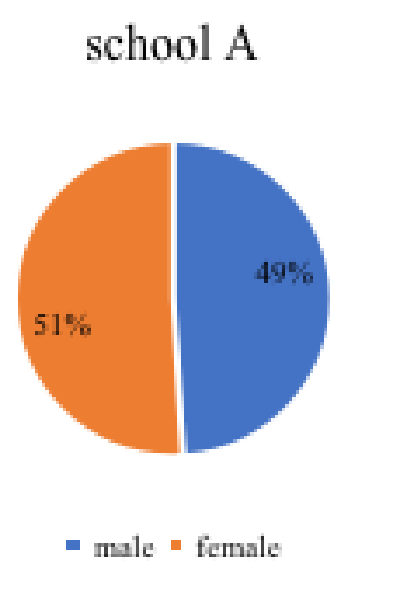

school B

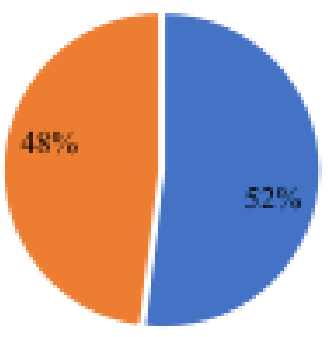

- male $=$ female school C

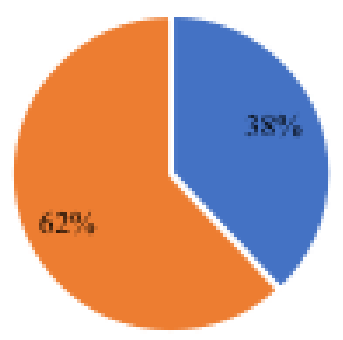

- male $=$ female

Figure4. Sex ratio of music association members in three schools

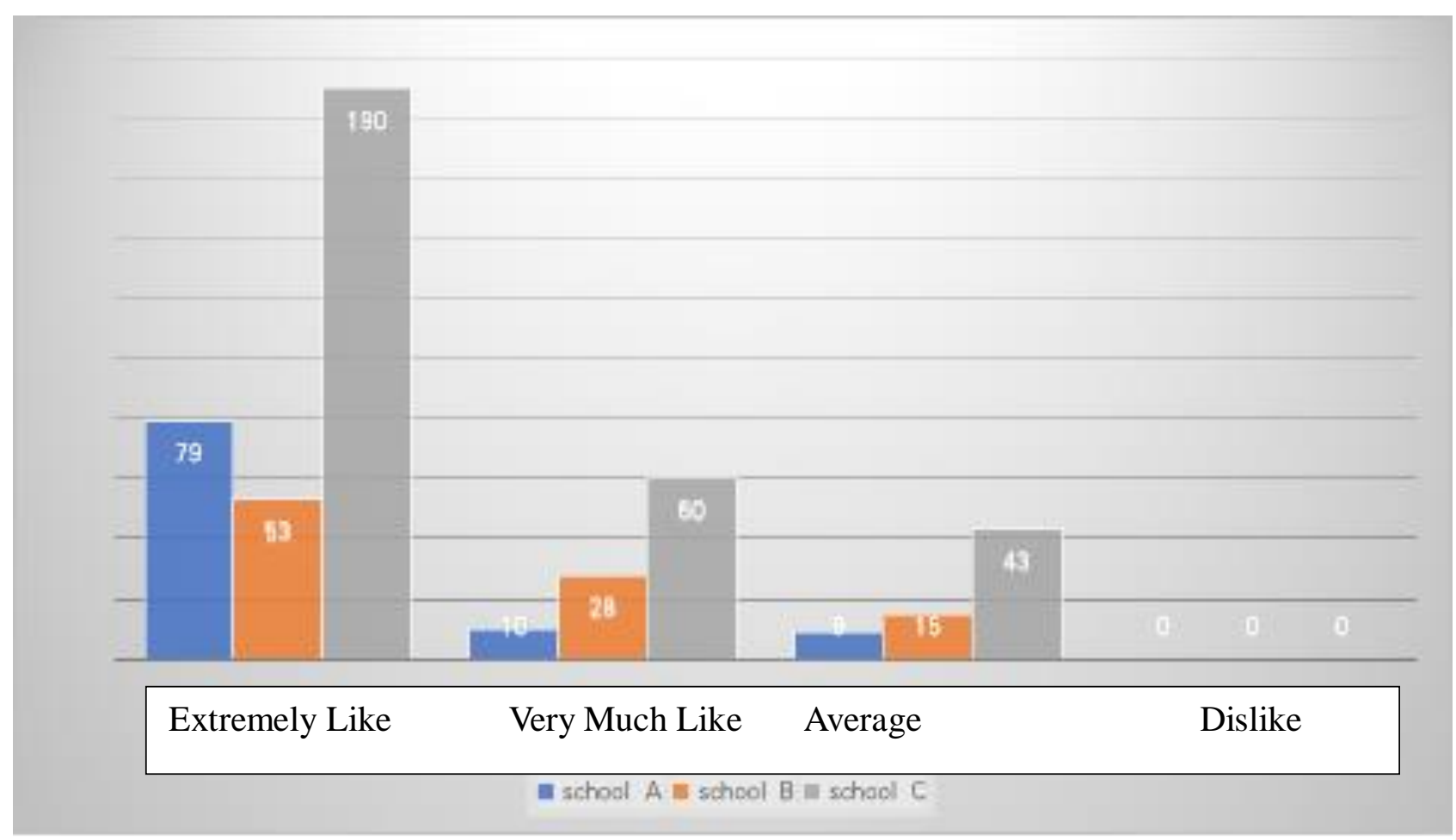

Figure5. Students' Interest Level in Music

Students' love for music is evaluated on a scale of four levels: Extremely Like, Very Much Like, Average and Dislike. In the survey, students in primary school, middle school and University show no Dislike to music, and Extremely Like to music accounts for $81 \%, 55 \%$ and $65 \%$ of the total number of participants respectively. It can be seen that the students at different educational levels cannot resist the unique charm of music generally.

In School A, primary school students are easy to show great enthusiasm for music because of their young mental development status and curiosity; In School B, with the gradual maturity of psychological and physiological aspects, the preferences of middle school students are gradually clear, and music activities are easy to become the choice of most middle school students after study; In School C, college students have more independent time, and music association activities will be the choice for most college students to relax, study, choose and make friends after their studies.

\section{Analysis of Music Education Function of School Associations}

\section{Students' Experience in Participating in Music Associations}

Table1 Survey results of students' experience in participating in music associations 
International Journal of Engineering Applied Sciences and Technology, 2021

Vol. 6, Issue 1, ISSN No. 2455-2143, Pages 29-42

Published Online May 2021 in IJEAST (http://www.ijeast.com)

\begin{tabular}{|c|c|c|c|c|c|c|}
\hline \multirow[t]{2}{*}{ Investigation items } & \multicolumn{2}{|c|}{ School A } & \multicolumn{2}{|c|}{ School B } & \multicolumn{2}{|c|}{ School C } \\
\hline & yes & no & yes & no & yes & no \\
\hline $\begin{array}{l}\text { Do you think participation in music associations has } \\
\text { an impact on your studies }\end{array}$ & $33 \%$ & $67 \%$ & $69 \%$ & $31 \%$ & $41 \%$ & $59 \%$ \\
\hline $\begin{array}{l}\text { Can I participate in music association activities on } \\
\text { time }\end{array}$ & $97 \%$ & $3 \%$ & $76 \%$ & $24 \%$ & $56 \%$ & $44 \%$ \\
\hline $\begin{array}{l}\text { Are you satisfied with the music association } \\
\text { activities currently carried out by the school }\end{array}$ & $96 \%$ & $4 \%$ & $77 \%$ & $23 \%$ & $75 \%$ & $25 \%$ \\
\hline Does your music association have a fixed venue & $100 \%$ & $0 \%$ & $90 \%$ & $10 \%$ & $75 \%$ & $25 \%$ \\
\hline $\begin{array}{l}\text { Have you ever had a public performance experience } \\
\text { in this section }\end{array}$ & $80 \%$ & $20 \%$ & $58 \%$ & $42 \%$ & $47 \%$ & $53 \%$ \\
\hline
\end{tabular}

It can be seen from the above table that in School A, the number of primary school students who think that participating in music associations has no impact on their studies is twice as many as those who think that participating in music associations has an impact on their studies, and $97 \%$ of primary school students can participate in school music association activities on time, and there are fixed venues for School A music association activities. About $80 \%$ of primary school students have public performance experience, and the other $20 \%$ have no public performance experience.

In School B, the vast majority of middle school students think that participation in music associations will have an impact on their studies. A small number of students think that participation in music associations will not affect their studies. More than $76 \%$ of middle school students can participate in school music association activities on time. More than half of the middle school students have the experience of performing in public.

In School C, most students think that participation in music associations has no effect on their studies. In addition, students in $\mathrm{C}$ School are more free to participate in association activities, and their time can be mor easily arranged by themselves. More than half of the students can participate in every music association activity on time. At the university stage, the number of students who have performed in public is $12 \%$ less than that who have not.

It can be seen that the enthusiasm of students in the three schools to participate in music association activities is good, and they are more satisfied with the development of music association in their schools, with satisfaction rates of $96 \%, 77 \%$ and $75 \%$ respectively. However, there are a few "dissatisfaction" in middle School and University, which shows that there are still some problems in school music associations, which can not meet the needs of all students. More than $75 \%$ of the students in the three schools said that there were fixed venues for music association activities, indicating that the current venues of the three schools can meet the needs of the vast majority of students' association activities. But there were still some students who were eager for new music venues and facilities. With the diversification of school education, there are more and more opportunities for students to perform and perform on the stage, which shows that schools are paying more and more attention to give students chances to perform in public. 
International Journal of Engineering Applied Sciences and Technology, 2021

Vol. 6, Issue 1, ISSN No. 2455-2143, Pages 29-42

Published Online May 2021 in IJEAST (http://www.ijeast.com)
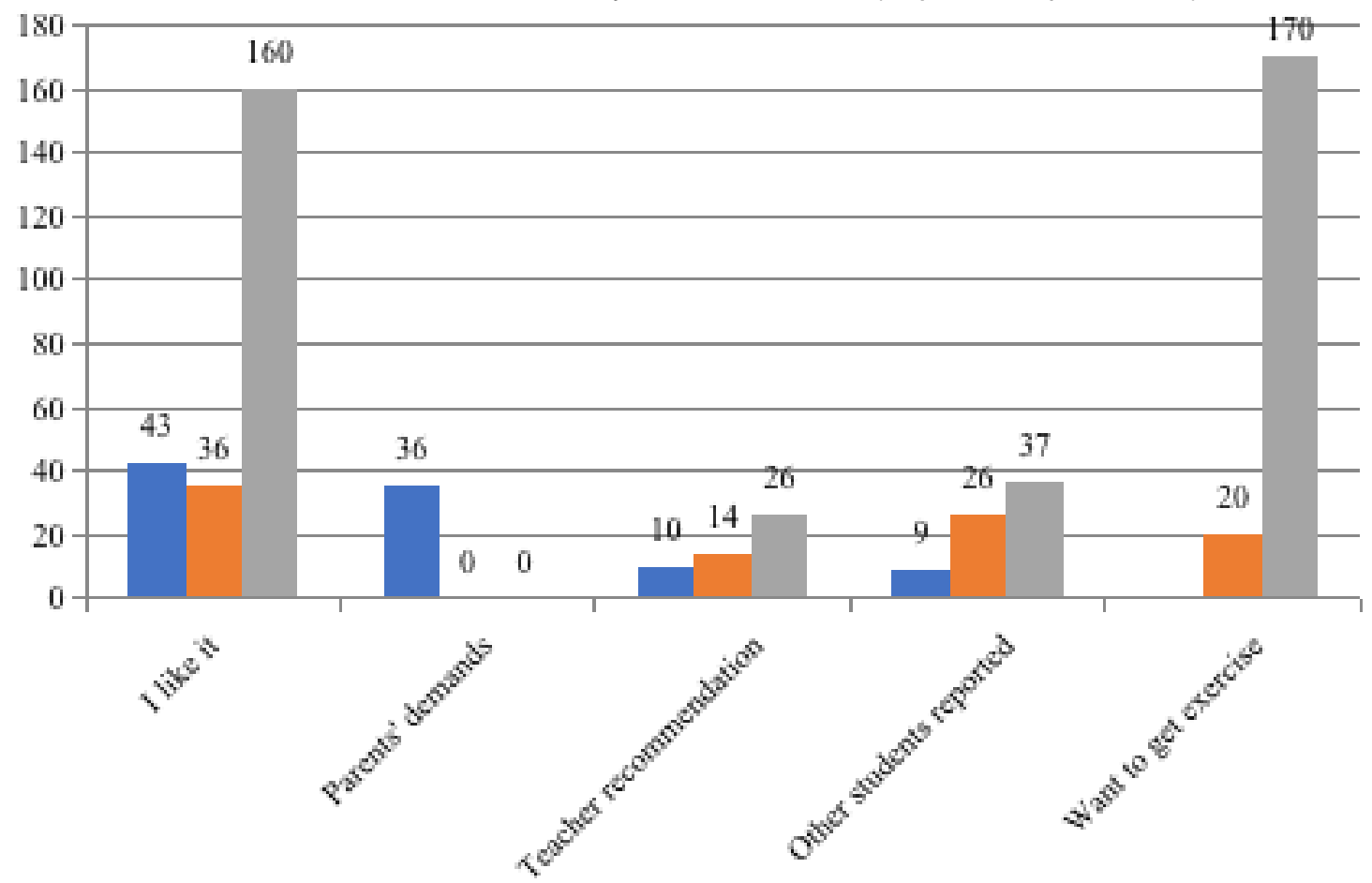

school A school B $\quad$ school C

Figure6. The reasons why students from three schools participate in music associations

It can be seen from the above figure that most of the students in School A participate in music associations because of their own preferences and parents' requirements, and a very small number of students are recommended by teachers and influenced by other students; In School B, most students participate in music associations because of their hobbies, while a small number of students participate because they are influenced by other students,want to get exercise or by teachers' recommendation .Most of the students in $\mathrm{C}$ school participate in music associations because of their own hobbies and want to get exercise. They are less influenced by teachers' recommendation and other students. It can be seen that no matter the stage of educational level, music associations are very attractive to students. Students in each stage have a strong curiosity about the music world and want to explore it.

Students' Participation Purpose in Music Associations 


\section{International Journal of Engineering Applied Sciences and Technology, 2021 \\ Vol. 6, Issue 1, ISSN No. 2455-2143, Pages 29-42 \\ Published Online May 2021 in IJEAST (http://www.ijeast.com)}

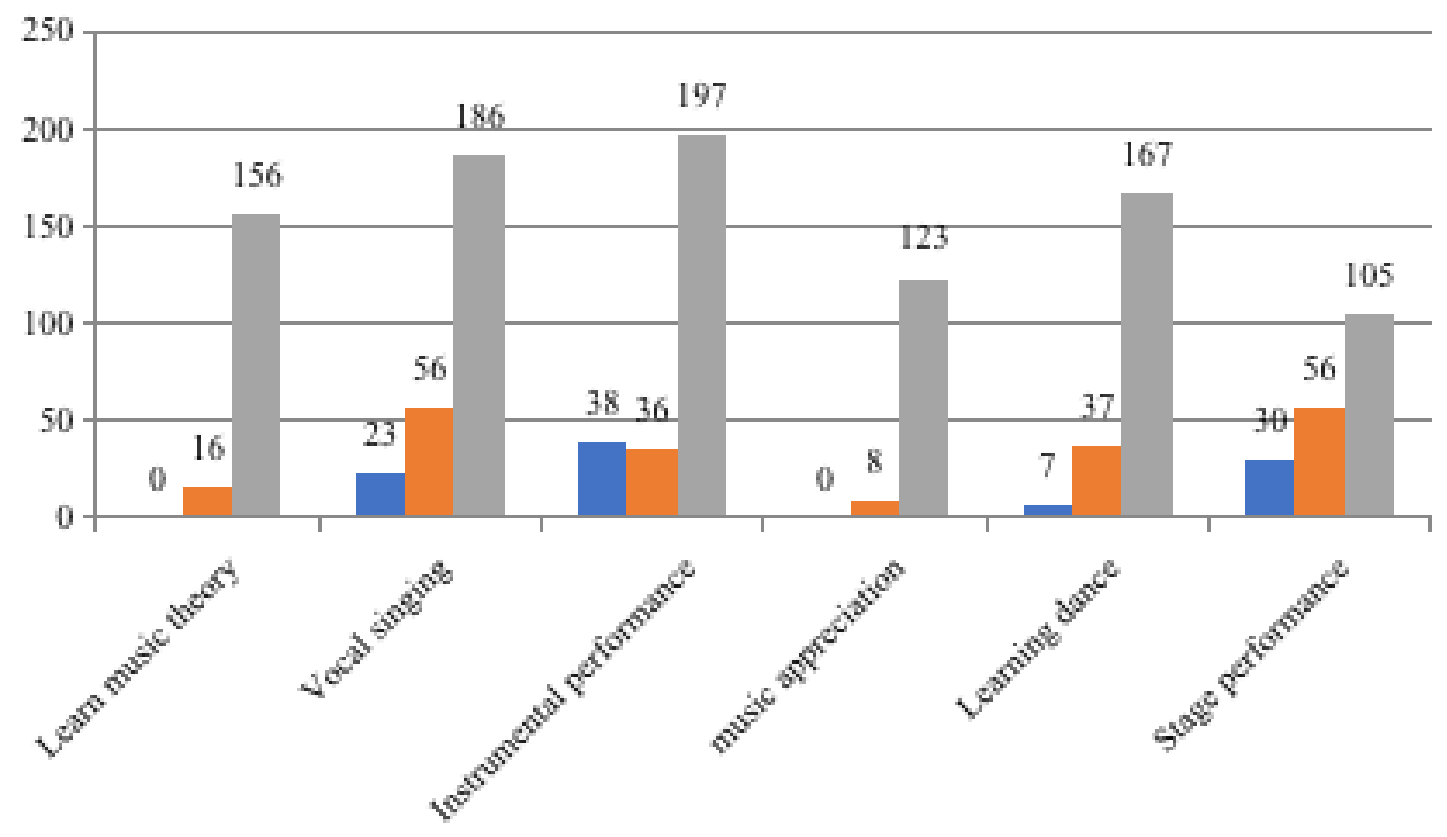

school A 1 school B E school C

Figure1. The progress that students in three schools want to make through music associations

From the above figure, it can be seen that the purpose of students participating in music associations in School A is mainly instrumental music performance, vocal music singing and stage performance, and a few primary school students want to learn dance when they participate in music association activities. In School B, most of the middle school students are eager to learn vocal music, stage performance, instrumental music performance and dance. A few middle school students want to learn music theory knowledge and improve their music appreciation ability. The students of School $\mathrm{C}$ have the greatest curiosity about the music world that spans the full range of participation purposes, including music theory learning, vocal singing, instrumental performance, music appreciation, dance learning and stage performance. Among them, most students want to learn music theory knowledge, vocal music singing, instrumental music performance and dance through participating in music associations while a few express their desire to learn stage performance and improve their music appreciation ability.

\section{CONCLUSION}

With the development of the domestic curriculum reform in China, student associations are booming, and the activities of student associations in music education tend to be diversified. The booming of school music association activities has greatly mobilized students' enthusiasm and passion for music learning. Students in various learning periods are more and more inseparable from the schools to carry out such learning activities. Through this survey, we can see that the music association activities of the three schools in Yaodu District are well developed, although there is still room for development. We should pay attention to the inheritance and cultivation of folk music by community music education, promote the healthy development of music community efficiency, and strengthen the cooperation and exchange of students' music community among schools, It is believed that the student music association will play a more positive role in promoting the all-round development of students, and the music education in Yaodu District will also make greater progress. Looking into the future, I believe that the development of the second classroom of School Associations will also become a major position for schools to cultivate students with all-round development of morality, intelligence, sports, beauty and labor.

\section{Suggestions for School Music Association Program Development}

Based on above-mentioned findings, this study makes suggestions to the music association directors, school administrators and government officers as such:

1 Pay attention to the inheritance and cultivation of the music education of the community to the national music. National music represents the common character, psychological quality and aesthetic taste of a nation, and is the symbol of national spirit. The survey found that in the teaching process of students' music associations in the three schools, the music associations in schools are relatively weak in the inheritance of national music, and the types of associations are not rich enough to meet the students' learning and appreciation of Chinese national music. 


\section{International Journal of Engineering Applied Sciences and Technology, 2021 \\ Vol. 6, Issue 1, ISSN No. 2455-2143, Pages 29-42 \\ Published Online May 2021 in IJEAST (http://www.ijeast.com)}

Therefore, the author suggests that the schools should attach importance to and organize the establishment of a variety of Chinese folk music associations, equipped with professional instructors, and use multimedia technology to promote students' understanding of folk music, so as to make folk musical instruments enter daily learning, and increase the opportunities for most students to contact, learn and enjoy folk music, and help students understand music culture and cultivate their patriotic feelings.

2 Promoting the diversification of music associations. The multi-dimensional development of school music community efficiency will be affected by the frequency, content and quality of community activities. Through the above analysis, it is not difficult to see that the schools' music associations have clear pertinence and direction for students' training, and the music education activities are also relatively diversified. However, some students still complained that the school music association can not meet their needs for music exploration.

3 The music association should arrange the activity time reasonably and set strict discipline to the students. To avoid the students' low enthusiasm in participating in music association learning and the phenomenon of students' incomplete music learning caused by the large frequency difference of music association activities, and to avoid the influence of students' participation in music association activities on their studies as far as possible;

4 Music associations in the school should pay more attention to the problem of insufficient equipment and venues, and seek resources to provide sufficient and quality activity equipment and venues as far as possible, so that students can have a more comprehensive and close understanding and learn music.

5 With the help of the platform of music associations, students' stage performance opportunities will be increased. At the same time, various music associations carry out multi-dimensional teaching in music education and integrate music theory, music appreciation and other related topic into daily music teaching activities of music associations, so as to cultivate students' holistic development, either psychological, physical, emotional or educational.

6 Strengthen the cooperation and program exchange in students' music associations among schools. Educational experience can be more fruitful when it is exchanged and shared with more participants. The investigation found that there is comparatively insufficient communication, cooperation and interaction among the music associations. Therefore, the author suggests that the schools should strengthen the cooperation and exchange, make full use of the combined resources to provide learning opportunities for a larger number of students .
VIII. REFERENCE

1 Chen Libei. The cultivation of normal students' teaching practice ability by music associations [D]. Yunnan Normal University, 2015

2 Chen Xianghui. Research on the path of music education to strengthen the campus culture construction of non art vocational colleges -Taking Henan Vocational College of applied technology as an example [J]. Northern music, 2019,39 (05): 135-136

3 Chen Yang. Analysis on the problems of music quality education in the construction of campus culture [J]. Science and education Wenhui (next issue), 2018 (02): 42-43

4 Chen Zhang. Analysis on the current situation and problems of music education for college students in China -- Taking Huazhong Agricultural University as an example [J]. Journal of Huazhong Agricultural University (SOCIAL SCIENCE EDITION), 2011 (06): 124127

5 Computers - Affective Computing; Researchers from National Cheng Kung University Provide Details of New Studies and Findings in the Area of Affective Computing (Automatic Ecg-based Emotion Recognition In Music Listening)[J]. Journal of Mathematics,2020.

$6 \mathrm{Fu} \mathrm{Li}$. Analysis of the current situation of music teaching in primary and secondary schools under the background of music teaching reform in normal universities and countermeasures [J]. Northern music, 2014 (07): 135-136

7 Han Rui. Investigation and Research on the development status and Countermeasures of music association activities in Bayi Primary School of Taiyuan [D]. Xinxiang: Henan Normal University, 2018

8 Jin Yuxiang. Pay attention to music education and promote all-round development $[\mathrm{J}]$. Educational research of Tsinghua University, 1991 (02): 70-74

9 Li Chao. Research on Teaching Strategies of primary school folk music [J]. Academic weekly, 2020 (13): 145-146

$10 \mathrm{Li}$ Wenyao. Investigation and Reflection on the current situation of primary school music associations [D]. Central China Normal University, 2015

11 Liu Hui. Research on the second classroom activities of TCFL based on Project Teaching [D]. Shandong University, 2014

12 Liu Yahe. The influence of high school music education on quality education and suggestions [J]. Chinese writer, 2021 (01): 171-172 
13 Ma Hongxuan, Shang Jie, Dong Ling. Exploration of the application of music associations in the work of the Communist Youth League [J]. Northern music, 2019, 39 (14): $238+$ 240

14 Ma Qing. Research on the construction of campus music culture [D]. Hunan Normal University, 2009

15 Networks - Telecommunications; Investigators from Pukyong National University Target Telecommunications (Joint Angle, Velocity, and Range Estimation Using 2d Music and Successive Interference Cancellation In Fmcw Mimo Radar System)[J]. Telecommunications Weekly,2020.

16 Shen hang. Research on the second classroom teaching activities of primary school music in Taiwan [D]. Minnan Normal University, 2019

17 Tong Yifan. How to effectively improve the comprehensive artistic quality of secondary vocational school students through chorus training [J]. Northern music, 2019,39 (22): $195+$ 207

18 Wang Ting. Investigation and Research on the current situation of science and Engineering College Students' participation in music association activities [D]. Northeast Normal University, 2018

19 Yi Zhenfa. How can music education in middle school "sound into the heart" [J]. Drama House, 2021 (13): 120-121

20 Zhang Bilan. Examples of high school music teaching in the context of core literacy [J]. Contemporary teaching and research, 2020 (03): $127-128$

21 Zhang Xuan. Research on the current situation and development of college music associations [D]. Nanjing Art College, 2010 